\title{
SELECTION OF MARKETS FOR TEXTILE EXPORT USING THE ADEQUATE PORTFOLIO
}

\author{
Viktorija Stasytyte* \\ Aleksandras Vytautas Rutkauskas ${ }^{* *}$ \\ Egle Celiešiene $e^{* * *}$
}

Received: 9. 3. 2021

Professional paper

Accepted: 27. 11. 2021

UDC 677:339.56

DOI https://doi.org/10.30924/mjcmi.26.2.15

\begin{abstract}
Textiles is one of the largest industries in the world, creating significant volumes of trade, export, and jobs. In the European Union, this industry is essential and attempts to retain and increase competitiveness. Most of the textile and clothing sector production is exported; thus, adequate orientation to export markets is essential. The paper's objective is to determine the countries suitable for exporting the textile production of Lithuania and similar countries using the adequate portfolio model. The adequate portfolio treats the export possibilities according to three
\end{abstract}

Abstract

\section{INTRODUCTION}

The paper analyses the textile and clothing sector. Along with agriculture, the textile industry is one of the biggest industries in the world, creating jobs for many people (Bathrinath et al. 2020). The textile and clothing sector performs a set of production activities from natural (cotton, flax, wool, etc.) or synthetic (polyester, polyamide, etc.) fibre processing to yarn and fabrics. Also, parameters: return, reliability, and risk. Clothing annual average index data across countries obtained from the Eurostat database were used for calculations. After performing the research, three portfolio cases were proposed, and the most profitable export countries and their given return were determined. Research results can be applied to the whole country and for individual textileexporting enterprises.

Keywords: textile industry, clothing, export, production, portfolio, return, risk, reliability

the textile sector produces such materials as high technology-based synthetic yarn, bedding, industrial filters, and clothes. Recently, industrial textile production has achieved greater popularity in various human activity fields, and its variety has increased (Sun et al., 2015; Founda et al., 2018).

The textile and clothing industry across the European Union has deep traditions, and in some countries is treated as one of

\footnotetext{
Viktorija Stasytytė, Vilnius Gediminas Technical University, Institute of Dynamic Management, Sauletekio ave. 11, Vilnius 10223, Lithuania, E-mail: viktorija.stasytyte@vilniustech.lt, ORCID: https://orcid.org/0000-00033451-9233

** Aleksandras Vytautas Rutkauskas, Vytautas Magnus University, Education Academy, T. Ševčenkos str. 31, Vilnius 03111, Lithuania, E-mail: rjawamr@gmail.com, ORCID: https://orcid.org/0000-0002-8285-3642

****Eglè Celiešienè, Lithuanian College of Democracy, Studentų str. 39, Vilnius 08106, Lithuania, E-mail: egle. celiesiene@gmail.com, ORCID: https://orcid.org/0000-0001-7883-4505
} 


\section{Journal of Contemporary Management Issues}

the most crucial industry fields. Textile and clothing is a versatile sector that plays a vital role in the European production industry. The sector employs 1.7 million people, and its turnover accounts for 166 billion EUR. The industry experienced radical changes to retain its competitiveness and move towards high value-added products.

The Lithuanian textile and clothing sector today is experiencing good times. Along with increasing export to the European countries, China has opened its doors to Lithuanian textile producers. Chinese businesspeople have attended textile and fabric fairs. Chinese partners buy Lithuanian fabrics and products, even if they are relatively expensive. Lithuanian export to China is increasing. Overall, Lithuania exports a substantial amount of textiles and fabrics (80\%) (Naginionytè, 2016). However, textile producers encounter a challenge - they lack an experienced workforce. The textile and clothing industry is distinguished from other production industry fields due to its high labour intensiveness. Before Lithuania joined the European Union, it was attractive for foreign investors due to the traditions of this industry and its skilled and inexpensive workforce. After joining the European Union, the situation changed due to increased emigration. The lower labour supply in the country and steady economic growth has resulted in a substantial increase in labour costs (Skruibytè, 2010).

The existence and development of the modern textile industry are related to specific innovations, such as the adaptation of the LEAN methodology in this industry (Prasad et al., 2020), or considering the sustainable development principles in production and applying the relevant strategies to avoid harming the environment (Roy et al. 2020). The textile industry's environmental problems include intensive material usage, waste generation, and water pollution (Hasanzadeh et al., 2018). The textile industry encounters other risks, such as noise in production due to old machinery, overload, poor design (Jaiswal, 2016), and employee illnesses due to inhaling cotton dust or lifting heavy weights (Annapoorani, 2017). Thus the textile industry continuously faces more challenges, and it requires a thorough analysis.

As the textile industry needs a broad market, the majority of the final products are exported. Export market selection is an important challenge in contemporary business and receives great attention from researchers. Market orientation can help in the export market selection. Market orientation is essential while creating value for customers and seeking a competitive advantage (Ipek and Bıçakcioğlu-Peynirci, 2020). However, even exceptional trading results obtained in the local market cannot be directly transferred to foreign markets (Murray et al., 2007). Also, company market orientation in the local environment does not mean that the company will have the same success with product export (Cadogan et al. 2001) because international markets are far more complex than the local ones. European and Lithuanian textile industries have established themselves successfully in the export markets; however, there is room for improvement. For example, there is a lack of research on how to select markets for successful exporting. This research gap will be filled by the research presented in this paper.

The research objective is to use an adequate portfolio model to determine the markets for exporting Lithuania's textile production. The particular value of the research lies in the fact that the results can be applied to the whole country and the separate exporting companies. Furthermore, the research results can be used by other European countries with similarly sized textile industries. 
The structure of the paper is as follows. The following section is devoted to the textile market analysis. The third section analyses the trends of the Lithuanian textile market. The fourth section presents the research methodology - the adequate investment portfolio. In the fifth section, the research results are presented in the form of three export portfolio cases. The conclusions of the paper summarise the obtained results, present research limitations and further research directions.

\section{EUROPEAN TEXTILE MARKET ANALYSIS}

The textile and clothing sector creates $3 \%$ of the value added and employs $6 \%$ of the production sector workforce in Europe. In the EU, the clothing industry mainly operates as small and medium enterprises. Companies with fewer employees constitute $90 \%$ of the industry and create around $60 \%$ of value added. The leading producers of textile and clothing are Western European countries that produce about three-fourths of EU production. Southern countries, such as Italy, Greece, Portugal, and some new EU member states significantly contribute to the overall production of clothing. Otherwise, Northern countries primarily produce technical textiles. Approximately $20 \%$ of EU products are exported outside of the EU.

Companies producing textiles reduce or abandon the mass production of simple products and concentrate on more diverse, higher value-added products. Such direction of production helps companies remain competitive. European enterprises are the leading producers in the technical and industrial textile and non-woven product markets (filters, hygiene products, automobile textile, and materials for medicine) and in the field of high-quality, exceptional design clothing. European textile producers may keep producing high value-added products and thus strengthen the positions of their industry sector. Textile companies often buy services or allocate their labour-intensive activities, for example, decoration of clothing, to countries where labour is less expensive, thus obtaining a better market position.

Globalisation and technology development require changes in how textile and clothing companies cooperate. Local cooperation is a positive trend; however, it has not enabled the production chain to remain geographically closer to the European market (Textiles and Clothing in the EU, 2020). The main indicators of the textile and clothing industry in the EU-27 countries are presented in Table 1.

Table 1. EU-27 indicators for 2019

\begin{tabular}{|l|c|c|c|}
\hline & Measurement units & Textile & Clothing \\
\hline Turnover & Bill. EUR & 88,8 & 72,8 \\
\hline Investment & Bill. EUR & 3,4 & 1,40 \\
\hline Companies & Number & 50,947 & 108,758 \\
\hline Workforce & 1000 employees & 593 & 922 \\
\hline Export & Bill. EUR & 26 & 35 \\
\hline Import & Bill. EUR & 29 & 80 \\
\hline Trade balance & Bill. EUR & -4 & -44 \\
\hline
\end{tabular}

Source: Facts and Key Figures (2020) 


\section{Journal of Contemporary Management Issues}

In 2018, the textile and clothing industry created $5 \%$ of all production industry jobs and $9 \%$ of all production companies. Investment accounted for $1 \%$, value-added for $2 \%$, production value for $2 \%$, and turnover for $2 \%$ of manufacturing industry activities. Almost all (99.8\%) companies operating in the textile and clothing industry were micro-, small and medium enterprises. Of all textile companies, $67 \%$ produced clothing, and $33 \%$ of companies produced textiles. From 2009 to 2018, the number of employees in this field decreased, and the value-added of one employee increased (from 20,800 EUR to 30,200 EUR). However, the age of the industry employees increased: in 2018, the industry employed $35 \%$ of employees older than 50 years, compared to $24 \%$ in 2009 . In terms of gender, women dominated $(70.8 \%)$.

The textile and clothing sector turnover analysis indicates that textiles accounted for $51 \%$, clothing for $45 \%$, and human-made fibres for $4 \%$ in the overall 162 billion EUR turnover in 2019. Production according to product types is presented in Figure 1.

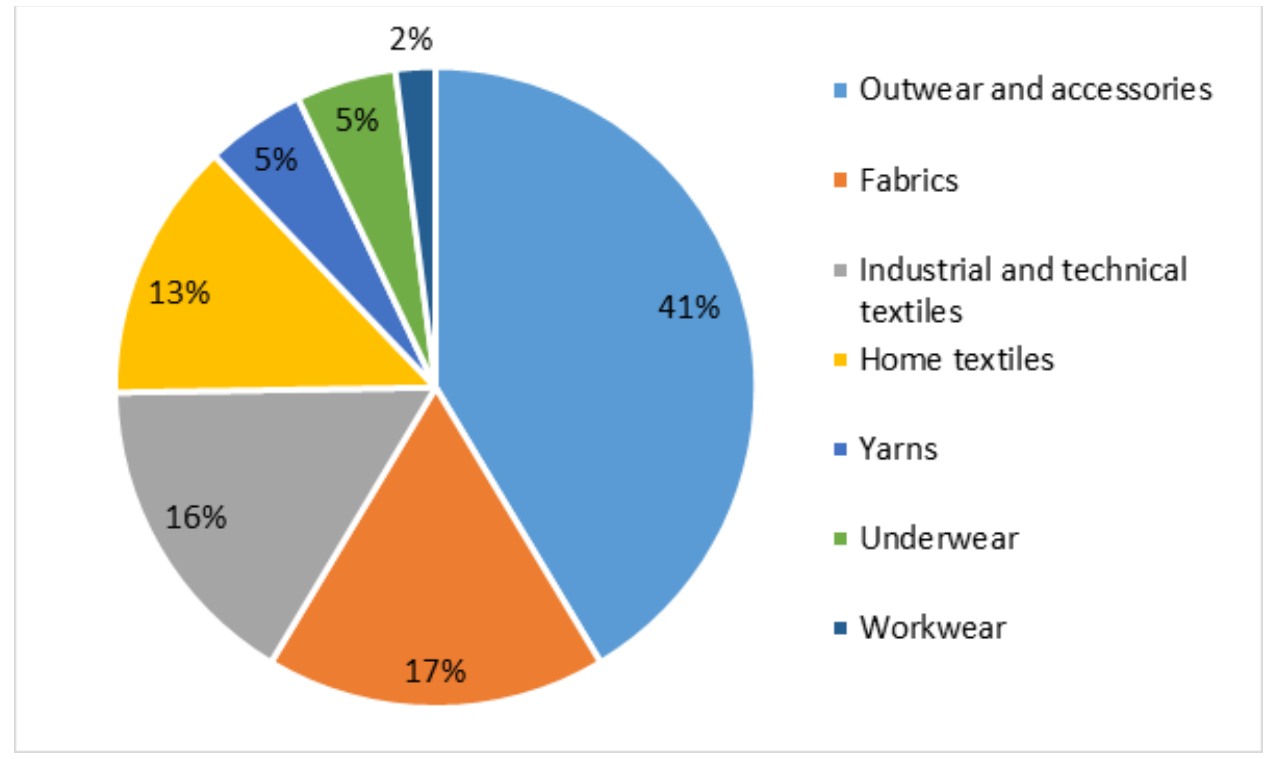

Figure 1. EU textile and clothing industry production by sub-sector, 2018

Source: Facts and Key Figures (2020)

The most significant investment in the textile and clothing industry in 2018 was in Italy, Germany, France, Portugal, and Poland. In terms of household consumption, EU citizens spent on average 600 EUR annually on clothing. In Lithuania, this amount was 450 EUR; thus, less than average. In Latvia, it was 340 EUR, and in Estonia, it was 490 EUR. The highest spending on clothing was recorded in
Luxembourg, at 1380 EUR. Overall, EU households in 2018 spent around 264 billion EUR on clothing, which grew by $10 \%$ from 2008 to 2018. The clothing category was the first in online shopping in 2019.

The European textile industry has leading positions in the world. EU export to lower-income countries accounts for about one-third of the world market. As a single 
market, the EU produced products of good quality and exceptional design that are popular around the world. EU gained its worldleading position in the textile and clothing sector due to high specialisation, flexibility, and continuous adaptation of the production structure to market needs, developing technical textiles for industrial needs. Due to its popularity, the export from the European market has recently increased by $13 \%$, and import has only increased by $4 \%$.

The textile and clothing sectors continually increased trade flows worldwide. The growing role of markets in lower-income countries and new possibilities of textile product use in such fields as the aerospace industry, medicine, construction and architecture, transport, and self-security suggest the great importance of better accessibility of non-EU markets (International Trade, 2020).

EU textile and clothing sector exports in 2018 increased by 7\%, compared to 2017 and reached a value of 50 billion EUR.
Industry exports amounted to $28 \%$ of the annual turnover and have increased during the last decade. These numbers indicate the global position of the European textile and clothing enterprises is becoming more important.

The demand for European high-quality textile products and luxury clothing is increasing in higher-income countries, such as the USA, Switzerland, Japan, and Canada, and in lower-income countries, such as China or Hong Kong, Russia, Turkey, and the Middle East. Export from Europe benefits from the rapid economic growth in the lower-income countries and better market accessibility due to more active cooperation with South Korea, Canada, or Japan (The European Apparel and Textile Confederation, 2020). EU exports most of its textile and clothing to the United Kingdom, Switzerland, USA, China, Russia, Turkey, Hong Kong, Japan, Morocco, and Norway. The export data of EU textile fibres are presented in Table 2.

Table 2. EU-28 (EXTRA) textile fibre export (000 EUR)

\begin{tabular}{|l|c|c|c|c|c|c|c|c|}
\hline Years & $\mathbf{2 0 1 1}$ & $\mathbf{2 0 1 2}$ & $\mathbf{2 0 1 3}$ & $\mathbf{2 0 1 4}$ & $\mathbf{2 0 1 5}$ & $\mathbf{2 0 1 6}$ & $\mathbf{2 0 1 7}$ & $\mathbf{2 0 1 8}$ \\
\hline Austria & 493,960 & 422,757 & 406,536 & 434,603 & 540,919 & 606,905 & 644,431 & 672,042 \\
\hline Belgium & 299,287 & 323,298 & 367,101 & 402,122 & 423,267 & 392,348 & 399,318 & 511,380 \\
\hline Bulgaria & 17,926 & 26,756 & 23,011 & 20,224 & 18,409 & 18,607 & 21,951 & 24,933 \\
\hline Cyprus & 135 & 178 & 268 & 474 & 592 & 695 & 1,081 & 1,189 \\
\hline Czechia & 35,238 & 44,012 & 42,305 & 39,855 & 43,745 & 45,092 & 48,702 & 51,886 \\
\hline Germany & 732,988 & 718,880 & 749,380 & 741,082 & 735,759 & 616,736 & 840,211 & 806,018 \\
\hline Denmark & 3,781 & 6,174 & 4,363 & 2,179 & 2,824 & 3,715 & 26,298 & 22,815 \\
\hline Estonia & 2,620 & 4,783 & 6,202 & 6,563 & 8,966 & 11,614 & 11,260 & 2,726 \\
\hline Spain & 115,686 & 135,254 & 141,657 & 150,421 & 134,182 & 176,109 & 197,008 & 218,889 \\
\hline Finland & 16,303 & 3,746 & 1,920 & 3,648 & 3,213 & 4,034 & 8,497 & 3,376 \\
\hline France & 211,414 & 235,834 & 263,332 & 328,504 & 323,832 & 360,115 & 354,310 & 395,654 \\
\hline United Kingdom & 476,132 & 568,996 & 520,202 & 475,766 & 477,239 & 471,701 & 468,544 & 478,339 \\
\hline Greece & 228,563 & 409,553 & 355,032 & 291,709 & 289,332 & 309,186 & 339,450 & 329,236 \\
\hline Hungary & 26,536 & 28,309 & 31,590 & 30,520 & 30,345 & 31,555 & 31,451 & 31,897 \\
\hline
\end{tabular}




\section{Journal of Contemporary Management Issues}

\begin{tabular}{|l|c|c|c|c|c|c|c|c|}
\hline Ireland & 28,836 & 32,124 & 22,591 & 15,518 & 18,125 & 18,309 & 16,894 & 16,435 \\
\hline Italy & 170,487 & 188,291 & 184,942 & 189,208 & 214,188 & 194,791 & 198,484 & 188,196 \\
\hline Lithuania & 42,950 & 52,217 & 52,151 & 41,791 & 44,875 & 47,616 & 63,953 & 85,806 \\
\hline Luxembourg & 17 & 1 & 49 & 94 & 274 & 327 & 225 & 322 \\
\hline Latvia & 6,057 & 8,451 & 9,068 & 7,682 & 5,827 & 4,876 & 8,922 & 12,371 \\
\hline Malta & 64 & 54 & 63 & 82 & 75 & 68 & 589 & 430 \\
\hline Netherlands & 155,016 & 165,899 & 183,729 & 171,730 & 162,386 & 167,910 & 148,935 & 115,810 \\
\hline Poland & 56,419 & 81,091 & 98,982 & 103,219 & 108,933 & 133,298 & 150,909 & 148,310 \\
\hline Portugal & 100,621 & 93,500 & 90,906 & 86,507 & 81,145 & 68,229 & 81,203 & 81,833 \\
\hline Romania & 13,891 & 13,443 & 14,464 & 16,892 & 18,827 & 19,771 & 22,514 & 21,078 \\
\hline Sweden & 5,233 & 5,153 & 5,467 & 5,708 & 5,412 & 5,428 & 5,017 & 3,989 \\
\hline Slovenia & 728 & 1,783 & 1,882 & 1,108 & 1,365 & 1,213 & 1,439 & 1,474 \\
\hline Slovakia & 8,000 & 8,428 & 7,023 & 5,798 & 5,783 & 5,782 & 6,513 & 6,912 \\
\hline Croatia & 144 & 268 & 133 & 545 & 595 & 283 & 365 & 1,480 \\
\hline
\end{tabular}

Source: Eurostat (2020)

The MSCI Europe Textiles, Apparel and Luxury Goods Index (USD) partly reflects the textile market situation. The index comprises large and middle capitalisation company shares across 15 higher-income-country markets: Austria, Belgium, Denmark,
Finland, France, Germany, Ireland, Italy, Netherlands, Norway, Portugal, Spain, Sweden, Switzerland, and the United Kingdom. Annual index growth is shown in Figure 2.

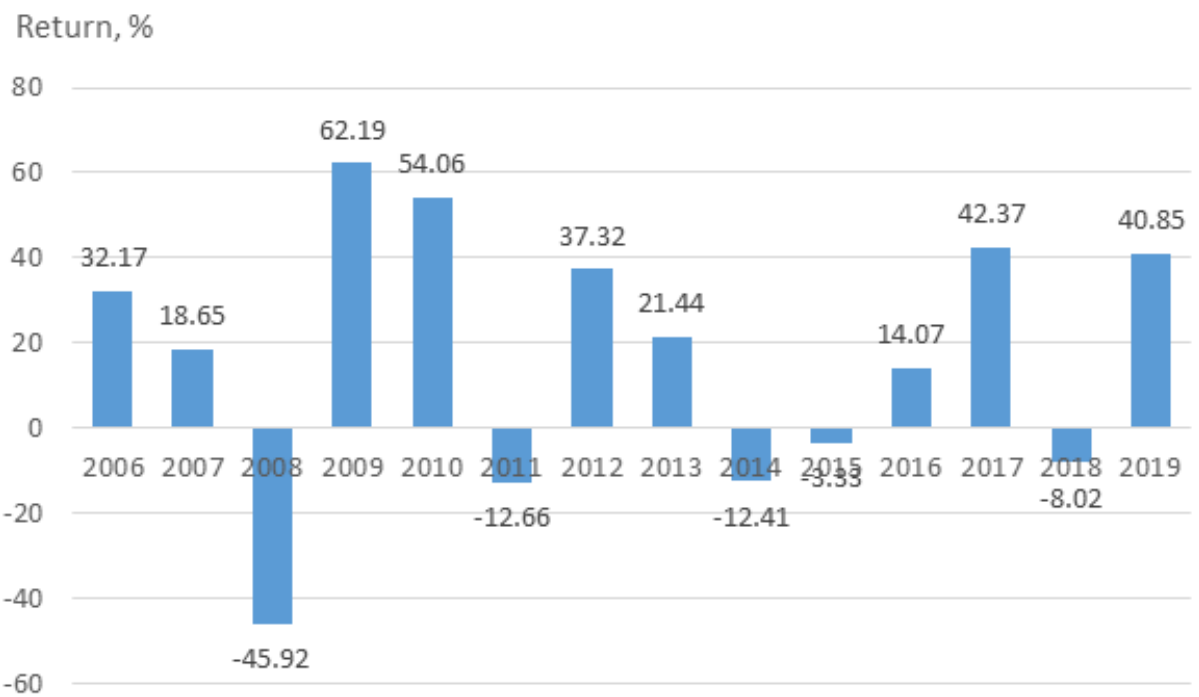

Figure 2. MSCI Europe Textiles, Apparel and Luxury Goods Index annual return Source: MSCI (2020) 
France has the greatest weight in the index (65.63\%). Other countries constitute smaller proportions: Germany, 16.37\%; Switzerland, $11.95 \%$; the United Kingdom, $2.32 \%$; Italy, $2.15 \%$.

\section{LITHUANIAN TEXTILE MARKET ANALYSIS}

The Lithuanian clothing and textile industry depends on exporting its manufactured products due to the small domestic market. Given the severe competition with Asian countries and the dynamic environment in the industry, it is increasingly challenging to select a strategy that ensures the competitive manufacturing of products and retaining or even increasing export volume. With trade liberalisation of textile and clothing products among EU and other countries, the EU market, Lithuania's leading trade partner, is importing an increasing amount of goods from Asian countries, such as China, Turkey, Pakistan, and Bangladesh. Growing export from Asia to the EU means that Lithuanian textile and clothing products can be replaced by Asian products. The growing import of textile and clothing products into Lithuania makes it more and more challenging to retain the production scope, employees, and foreign markets (Skruibyte, 2010).
Lithuanian textile and clothing industry export to the EU constitutes a tiny part of the overall world export. In this regard, Lithuanian textile producers and tailors have great unused opportunities to increase the export scope. The Lithuanian textile and clothing industry has long-lasting traditions and great experience in this field that are recognised in many Western European and other world countries. Some textile and tailoring companies have locally known brands that are also recognised in regional and foreign markets. By broadening the marketing activity and performing an effective sales support program, it is possible to increase export volume to the EU and other regions (Skruibytè, 2010).

The analysis of the Lithuanian textile market should include data about the amount of fabrics produced. Production decreased from 2000 to 2009, when it reached 13.1 million $\mathrm{m}^{2}$ (Figure 3). In 2010, production started to increase slowly and in 2018 amounted to 43 million $\mathrm{m}^{2}$. The production of cotton fabrics decreased from 55.1 million $\mathrm{m}^{2}$ in 2000 to 0.2 million $\mathrm{m}^{2}$ in 2018 . Production of woollen and linen fabrics also decreased from 15.4 and 17.8 million $\mathrm{m}^{2}$ in 2000 to 3.0 and 5.9 million $\mathrm{m}^{2}$ in 2018. Conversely, fabrics of synthetic fibres increased from 17.7 million $\mathrm{m}^{2}$ in 2000 to 33.9 million $\mathrm{m}^{2}$ in 2018 . 


\section{Journal of Contemporary Management Issues}

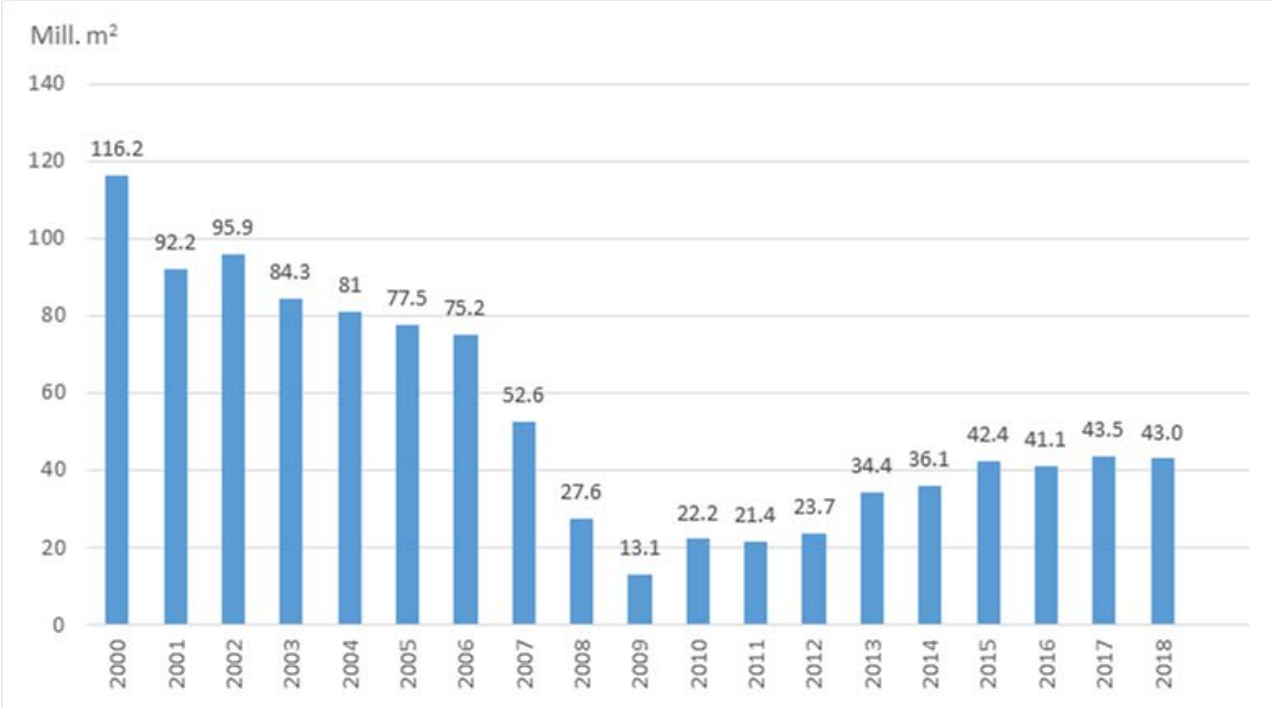

Figure 3. Production of fabrics in Lithuania

Source: Authors' calculations, based on Lithuanian statistics data (2020)

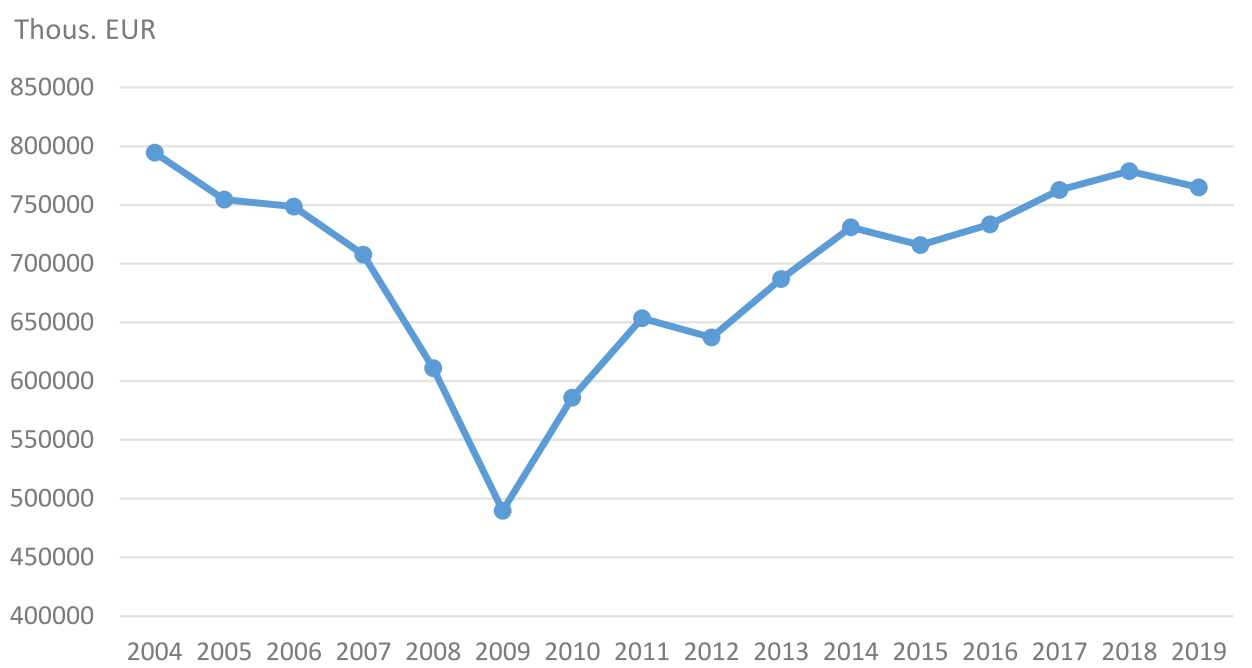

Figure 4. Export of textile materials and products of Lithuanian origin

Source: Authors' calculations, based on Lithuanian statistics data (2020)

The export of textile materials and products of Lithuanian origin decreased from 2004 and reached a low of 489.8 million EUR in 2009. In the next decade, exports began to grow and amounted to 764.8 million EUR in 2019.
The analysis by country and category shows that Lithuania exports most of its carpets to Poland, Sweden, and Finland, and a little bit less to Denmark, Germany, and Iceland. From 2005 to 2008, the biggest export was to Latvia. The export of 
unique fabrics, lace, and tapestry was mainly to Latvia, Estonia, Poland, Denmark, Belorussia, and Ukraine, albeit in decreasing amounts from 2004 to 2019. Impregnated, wreathed, coated, and laminated textile fabrics and industrial textile products were mainly exported to Germany, Latvia, Poland, the United Kingdom, Russia, and Indonesia. The export of this group increased in 2004 2019. Knitted materials were mainly exported to Poland, Latvia, Estonia, Sweden, Belorussia, and Ukraine.

Table 3. Export of products of Lithuanian origin by groups and countries, in thousand EUR

\begin{tabular}{|c|c|c|c|}
\hline & $\begin{array}{l}\text { Knitted clothes and } \\
\text { accessories }\end{array}$ & $\begin{array}{l}\text { Clothes and accessories, } \\
\text { except knitted }\end{array}$ & $\begin{array}{l}\text { Other finished textile } \\
\text { products, second-hand } \\
\text { clothes }\end{array}$ \\
\hline Ireland & $3,868.7$ & 190.7 & 93.6 \\
\hline Austria & $3,647.1$ & $1,667.2$ & 201.2 \\
\hline Belgium & $1,632.6$ & $8,438.5$ & 702.6 \\
\hline Bulgaria & 1.5 & 24.1 & 24.8 \\
\hline Czechia & $1,869.2$ & 263.2 & 359.8 \\
\hline Denmark & $21,910.2$ & $18,833.6$ & $6,912.9$ \\
\hline Estonia & 894.7 & $2,026.3$ & 566.4 \\
\hline Greece & 35.9 & 91 & 23.1 \\
\hline Spain & 273.1 & 429.2 & $1,130.4$ \\
\hline Italy & 3129.7 & $1,617.7$ & $4,652.4$ \\
\hline United Kingdom & $12,569.4$ & $27,499.3$ & $5,494.9$ \\
\hline Cyprus & 0.6 & 33.6 & 0.4 \\
\hline Croatia & 2.2 & & 1.6 \\
\hline Latvia & $1,612.9$ & $2,824.9$ & $2,182.1$ \\
\hline Poland & $1,068.8$ & $1,397.8$ & $2,261.2$ \\
\hline Luxembourg & 75.8 & 42.2 & 2.6 \\
\hline Malta & 1.1 & 0.4 & 0.6 \\
\hline Netherlands & $2,537.1$ & $2,072.1$ & $1,258.4$ \\
\hline Portugal & 18.5 & 83.3 & 21.3 \\
\hline France & $1,195.9$ & $16,889.1$ & $11,199.5$ \\
\hline Romania & 29.4 & 19.6 & 63.7 \\
\hline Slovakia & 255.7 & 27.1 & 8.1 \\
\hline Slovenia & 45.2 & 1.2 & $1,005.1$ \\
\hline Finland & $6,428.1$ & $9,036.9$ & $2,522.3$ \\
\hline Sweden & $19,497.5$ & $24,151.5$ & $18,098.7$ \\
\hline Hungary & 55.2 & 62.2 & 106.6 \\
\hline Germany & 35,468 & $48,847.4$ & $4,021.6$ \\
\hline
\end{tabular}

Source: Lithuanian statistics (2020) 


\section{Journal of Contemporary Management Issues}

Table 3 shows the export of some other categories of products and materials to the EU by country. Knitted clothes and accessories have been exported to Germany, Denmark, Sweden, and the United Kingdom. Of the non-EU countries, the biggest export was to Norway. Clothing and accessories, except for knitted products, have also been exported to these countries; another significant export destination was France. Other finished textile products have been exported to Sweden, France, Denmark, and non-EU countries as Japan, the USA, Norway, and Switzerland.

\section{METHODS}

The portfolio concept is used in many fields of research, in addition to investment and finance. The traditional perception of an investment portfolio is that it is a set of one-type assets belonging to one investor. This idea has been replaced, and the portfolio today is a set of various types of assets belonging to one investor. Relationships among the changing assets become more and more complex. Various types of derivative securities in a portfolio can lead to quite a complex set of interrelationships. Therefore, it is not surprising that portfolio construction methods are constantly and rapidly becoming more complex. The portfolio becomes an essential instrument of analysis that aims to investigate complex stochastic systems.

In textile and clothing export research, we will define the portfolio as a set of various possible foreign export markets. A portfolio technique will be applied to determine the optimal set of markets suitable for exporting textile and clothing products. We will also specify the optimal proportions for the distribution of production. The exporter as a subject is not described in detail here.
An exporter can be a company, a group of companies, or a country; thus, the research results are broadly applicable.

The adequate portfolio, or adequate portfolio for the stochastic nature of investment assets, will be applied in the performed experiment. This will allow assessing the export of products according to the size and reliability of export volume. The adequate portfolio model was created by A.V. Rutkauskas in 2000, and its application to various economic, financial, and investment problems has been widely documented (Rutkauskas, 2005, 2006; 2017; Rutkauskas and Stasytytè, 2011; 2020).

When we analyse the portfolio return concept, or, particularly, the concept of return on investments that belong to the portfolio, it should be noted that the average value of portfolio return is not the only or universally applied indicator of a particular portfolio. Expected or average profitability is a general state of portfolio return possibilities for all component assets. Moreover, this is the only one out of many characteristics, some of which do not raise such great interest as, for example, a quantile of a certain level. Average or mean profitability often does not belong to the set of attainable states. In every particular case, the mean profitability will be that of all the possibilities of profitability that are thoroughly described by their probability distribution. When describing the portfolio, we treat portfolio profitability as equivalent to portfolio return.

The profitability of investments in a portfolio is observed and realised both according to its mean values and to certain possible values that are explained by the investment market and acquisition prices. Thus, it is important for the investor to analyse a set of possible portfolio return expected values, not only the modern 
portfolio efficient frontier (Markowitz 1952; 1959). Consequently, the investor should look at the efficiency zone that is perceived as a set of efficient frontiers for all the quintiles of the probability distribution of selected investment possibilities. For this reason, the analysis of the efficiency line containing portfolios with the maximum mean is substituted with the analysis of the efficiency zone. The title of the adequate portfolio, or portfolio that is adequate to determine the investment profitability guarantee (reliability), shows that one of its main advantages is the reliability assessment of investment decisions (Rutkauskas 2000). In other words, portfolio adequacy is expressed by the situation in which such a portfolio model is developed that analyses every possibility of the expected profitability with regard to the guarantee of this possibility. As a result, the portfolio is adequate to the stochastic nature of the investment profitability possibilities (expected return).

According to the adequate portfolio, it is most important and clear to assess the attained reliability of the profitability possibility and the profitability, riskiness, and guarantee levels for the contemporary investor. Such outcomes are revealed by creating an effective surface in the threedimensional space: return, riskiness, and reliability (guarantee). The surface is formed as a result of the intersection of the survival functions (cumulative distribution functions) and isoguarantees of return levels. The concept of isoguarantee is not very common in the economic literature, but it supports a better explanation of decision making in a three-dimensional space. An isoguarantee is a line joining the points of the same guarantee (reliability) level in the return-riskiness-reliability surface. This surface helps find the highest-utility return value for the investor after selecting a utility function as a criterion.

While using the elements of the effective surface, it is worth paying attention to their measurement. As with analysing the stochastic (probabilistic) values or processes, it is common to measure the reliability by the survival function $\mathrm{S}(\mathrm{x})=1-\mathrm{F}(\mathrm{x})$. In the mentioned expression, $\mathrm{F}(\mathrm{x})=\mathrm{P}\{\xi<\mathrm{x}\}$ is the accumulated distribution function of the return.

The profitability and risk concepts are often applied to ground solutions in research, particularly the interaction of various related processes. However, this paper's logic views risk in terms of the ability to reflect both the possible losses of the investor due to the investment return riskiness and the investor's ability to cope with the effects of such riskiness.

The detailed anatomy of the adequate portfolio is presented in the authors' previous works (Rutkauskas, 2005; Rutkauskas and Stasytyte, 2020). Here it is only necessary to mention the role of the utility function while creating an adequate portfolio. A three-parameter utility function in the 'return-risk-guarantee' space is designed for the adequate portfolio (Figure 5). Approaching the set of adequate portfolio values indicates the most effective value and, in turn, the portfolio structure. We have already mentioned that the set of return values of the adequate portfolio is a net of survival functions and isoguarantees. In turn, the three-dimensional utility function is an intersection net of the separate 'return-risk' and 'return-guarantee' utility functions. 


\section{Journal of Contemporary Management Issues}

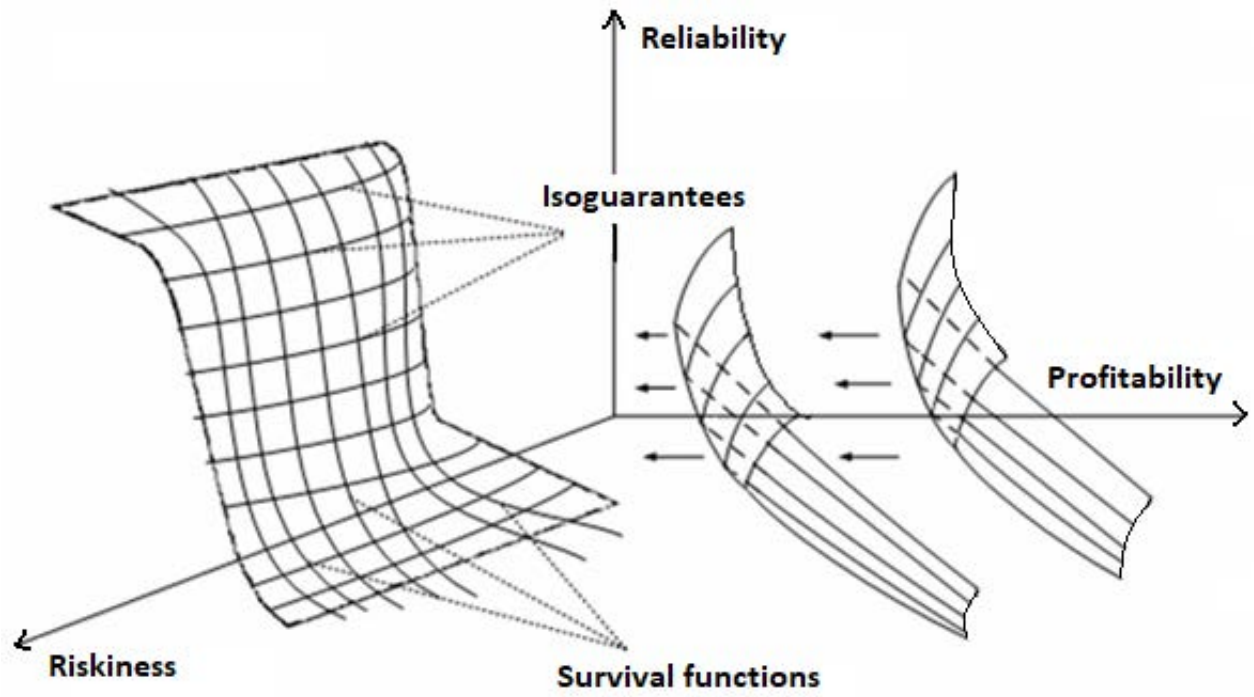

Figure 5. Utility surface approaching the possibilities' surface Source: Rutkauskas (2006)

Such elaboration of the schematic search for the portfolio solution is worth analysing because the stochastic programming task is being solved by applying graphical decision-making instruments.

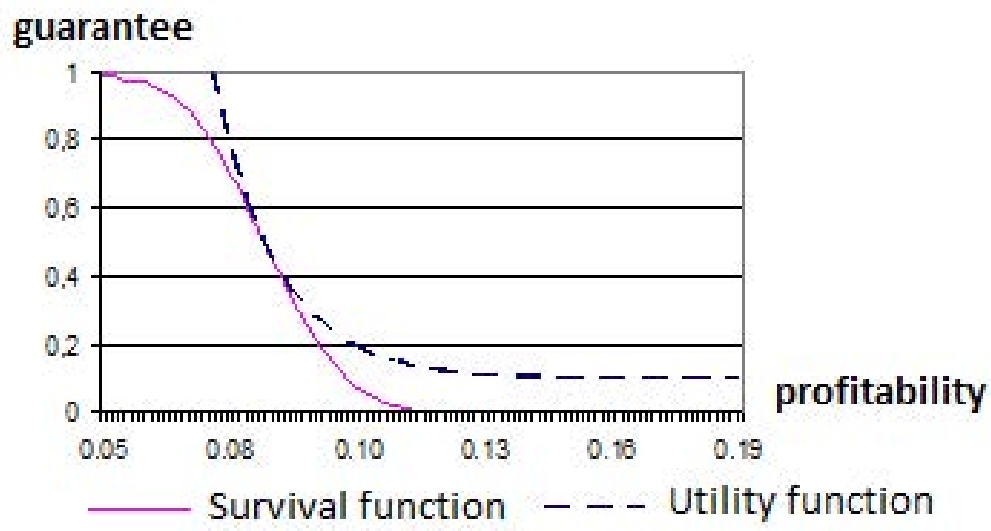

Figure 6. The touch of the survival function and utility function on a specific risk level the optimal solution

Source: Rutkauskas \& Stasytyte (2011) 
Figure 6 shows the decision-fixing moment in a two-dimensional plane (a section of the three-dimensional space). The obtained touchpoint shows the possibility of having the highest utility. After performing the technical procedure, we find the parameters of this point (its return, reliability, and riskiness), as well as the portfolio structure that allows such a solution.

Thus, the reliability of every point is analysed and described as a probability that investment return will not drop below a certain level using the adequate portfolio creation method. This lets us reveal the interrelation of the return guarantee and risk, as the variability of return possibilities, with the investor's utility function.

\section{RESULTS}

The adequate portfolio methodology will be applied to determine the most suitable countries for textile export. The statistical data to form the portfolio have been gathered from the Eurostat database: the clothing annual average index (Eurostat database 2020). Of 35 countries for which data were presented, the countries selected were those to which Lithuania exports most of its textiles and clothing. The descriptive statistics of the selected data are presented in Table 4.

Table 4. Descriptive statistics of the clothing annual average index

\begin{tabular}{|l|l|l|l|l|l|l|l|l|l|l|}
\hline & Mean & $\begin{array}{l}\text { Std. } \\
\text { err. }\end{array}$ & Median & SD & Variance & $\begin{array}{l}\text { Kurto- } \\
\text {-sis }\end{array}$ & $\begin{array}{l}\text { Skew- } \\
\text {-ness }\end{array}$ & Range & Min. & Max. \\
\hline Belgium & 95.67 & 0.92 & 93.87 & 4.11 & 16.86 & -1.52 & 0.41 & 12.01 & 90.42 & 102.43 \\
\hline Denmark & 102.34 & 1.29 & 101.75 & 5.75 & 33.11 & -0.40 & -0.33 & 20.4 & 90.4 & 110.8 \\
\hline Germany & 96.35 & 0.87 & 95.10 & 3.91 & 15.31 & -1.03 & 0.44 & 13 & 91 & 104 \\
\hline Estonia & 84.01 & 3.45 & 80.64 & 15.43 & 238.12 & -1.51 & 0.21 & 44.87 & 61.78 & 106.65 \\
\hline Ireland & 128.98 & 6.87 & 117.10 & 30.70 & 942.77 & -1.44 & 0.35 & 89.9 & 92 & 181.9 \\
\hline France & 98.36 & 0.47 & 98.29 & 2.10 & 4.39 & -1.74 & 0.12 & 5.83 & 95.56 & 101.39 \\
\hline Italy & 95.88 & 1.11 & 96.80 & 4.95 & 24.54 & -0.60 & -0.68 & 15.7 & 86.2 & 101.9 \\
\hline Latvia & 105.13 & 1.29 & 103.46 & 5.76 & 33.23 & -1.19 & 0.57 & 16.58 & 99.13 & 115.71 \\
\hline Netherlands & 102.81 & 0.59 & 102.30 & 2.63 & 6.92 & 1.11 & 1.10 & 10.26 & 99.4 & 109.66 \\
\hline Austria & 97.56 & 0.86 & 97.60 & 3.84 & 14.71 & -1.60 & 0.05 & 11.24 & 92.29 & 103.53 \\
\hline Poland & 131.72 & 7.44 & 125.85 & 33.27 & 1107.07 & -1.45 & 0.13 & 94.2 & 85 & 179.2 \\
\hline Finland & 97.15 & 0.46 & 96.49 & 2.08 & 4.32 & -0.59 & 0.46 & 7.48 & 93.9 & 101.38 \\
\hline Sweden & 95.75 & 1.14 & 95.22 & 5.09 & 25.89 & -1.21 & 0.27 & 15.46 & 88.27 & 103.73 \\
\hline UK & 113.38 & 4.62 & 103.70 & 20.66 & 426.99 & 0.92 & 1.33 & 71.9 & 93.9 & 165.8 \\
\hline
\end{tabular}

Source: Authors' calculations

Table 5 presents the annual increases of the clothing annual average index, according to which the growth of the index for the portfolio will be forecasted. 
Journal of Contemporary Management Issues

Table 5. Annual increases in the clothing annual average index

\begin{tabular}{|c|c|c|c|c|c|c|c|}
\hline & Belgium & Denmark & Germany & Estonia & Ireland & France & Italy \\
\hline 2001 & 1.004645 & 0.989824 & 1.005297 & 1.050826 & 0.970863 & 1.003663 & 1.00464 \\
\hline 2002 & 1.008366 & 1.029907 & 1.004215 & 1.048675 & 0.957531 & 1.006464 & 1.024249 \\
\hline 2003 & 1.009389 & 1.005445 & 0.991605 & 1.01131 & 0.96097 & 0.995235 & 1.020293 \\
\hline 2004 & 1.005083 & 0.99278 & 0.992593 & 0.997386 & 0.966769 & 1.00052 & 1.018785 \\
\hline 2005 & 0.995803 & 0.986364 & 0.978678 & 1.018203 & 0.975812 & 1.000416 & 1.011931 \\
\hline 2006 & 0.995569 & 0.967742 & 0.991285 & 1.030892 & 0.983692 & 1.00208 & 1.009646 \\
\hline 2007 & 1.001628 & 0.968571 & 1.008791 & 1.037875 & 0.968833 & 1.00467 & 1.006369 \\
\hline 2008 & 1.007586 & 0.992134 & 1.002179 & 1.045582 & 0.952772 & 1.005061 & 1.015823 \\
\hline 2009 & 1.003979 & 1.000991 & 1.013043 & 1.017131 & 0.882902 & 1.009764 & 1.002077 \\
\hline 2010 & 1.011141 & 1.00297 & 1.007511 & 1.027024 & 0.905614 & 1.002545 & 1.006218 \\
\hline 2011 & 1.014514 & 1.004936 & 1.020234 & 1.050667 & 0.98832 & 0.998173 & 1 \\
\hline 2012 & 1.010756 & 1.008841 & 1.02714 & 1.0629 & 1.004545 & 1.024207 & 1.021627 \\
\hline 2013 & 1.027172 & 0.996105 & 1 & 1.046027 & 0.976471 & 1.006852 & 1.006048 \\
\hline 2014 & 1.001106 & 0.98827 & 1.011179 & 1.020849 & 0.965709 & 0.998027 & 1 \\
\hline 2015 & 1.004722 & 0.98912 & 1.005025 & 1.026273 & 0.959693 & 0.98824 & 1.002004 \\
\hline 2016 & 1.0083 & 0.96 & 1.006 & 1.0354 & 0.976 & 1.0052 & 1.006 \\
\hline 2017 & 1.003967 & 0.985417 & 1.011928 & 1.017867 & 0.959016 & 1.001293 & 1.005964 \\
\hline 2018 & 1.00326 & 0.986258 & 1.000982 & 1.006927 & 0.992521 & 0.999503 & 1.003953 \\
\hline \multirow[t]{2}{*}{2019} & 1.008566 & 0.968917 & 1.020608 & 1.004994 & 0.990312 & 0.995825 & 1.002953 \\
\hline & Latvia & Netherlands & Austria & Poland & Finland & Sweden & UK \\
\hline 2001 & 1.009097 & 1.005927 & 0.991125 & 1.017604 & 1.009851 & 1.027982 & 0.91918 \\
\hline 2002 & 0.992581 & 1.025531 & 1.000213 & 0.993304 & 0.989219 & 1.021821 & 0.922572 \\
\hline 2003 & 1.025639 & 0.964891 & 0.996909 & 0.978652 & 0.998132 & 0.996549 & 0.958748 \\
\hline 2004 & 1.027027 & 0.982232 & 0.993051 & 0.972445 & 1.002496 & 0.968074 & 0.948813 \\
\hline 2005 & 1.001886 & 0.971808 & 0.993541 & 0.957497 & 0.993361 & 1.000671 & 0.947615 \\
\hline 2006 & 1.016226 & 1.003366 & 1.003034 & 0.94328 & 0.980576 & 1.015194 & 0.959571 \\
\hline 2007 & 1.02073 & 1.014604 & 1.022578 & 0.94183 & 1.005005 & 1.024651 & 0.959587 \\
\hline 2008 & 0.990839 & 0.999903 & 1.012994 & 0.949341 & 1.003073 & 0.993878 & 0.930108 \\
\hline 2009 & 0.947056 & 0.993775 & 1.014391 & 0.938596 & 1.007184 & 1.016641 & 0.915222 \\
\hline 2010 & 0.933689 & 0.992561 & 1.006785 & 0.96028 & 1.012482 & 1.024128 & 0.988421 \\
\hline 2011 & 0.991813 & 1.009762 & 1.026141 & 0.982968 & 1.020719 & 1.013285 & 1.031949 \\
\hline 2012 & 0.985878 & 1.006543 & 0.998408 & 0.957096 & 1.028925 & 0.995698 & 1.01032 \\
\hline 2013 & 1.005447 & 1.001649 & 1.008671 & 0.951724 & 0.98915 & 1.008847 & 1.012257 \\
\hline 2014 & 1.007124 & 0.98983 & 0.989822 & 0.951087 & 0.991923 & 1.008157 & 1.004036 \\
\hline
\end{tabular}


Management, Vol. 26, 2021, No. 2, pp. 255-276 V. Stasytytė, A. V. Rutkauskas, E. Celiešienė: SELECTION OF MARKETS FOR TEXTILE EXPORT ...

\begin{tabular}{|l|c|c|c|c|c|c|c|}
\hline 2015 & 0.996214 & 0.978569 & 0.998303 & 0.952381 & 1.005328 & 1.011429 & 1.005025 \\
\hline 2016 & 0.9999 & 1.009 & 1.009 & 0.953 & 0.9922 & 1.0373 & 1.002 \\
\hline 2017 & 0.992499 & 0.985828 & 1.01447 & 0.946485 & 0.986696 & 0.999904 & 1.028942 \\
\hline 2018 & 1.003628 & 0.999296 & 1.005569 & 0.960089 & 0.988458 & 0.997108 & 1.008729 \\
\hline 2019 & 1.016867 & 1.019215 & 1.005829 & 0.981524 & 0.99287 & 0.988977 & 0.996154 \\
\hline
\end{tabular}

Source: Authors' calculations

\subsection{First portfolio case}

In this export portfolio, each of the 14 countries receives an equal export volume, 0.071429 . Figure 7 presents portfolio results. We can see that the annual growth in most years is lower than 1 , and the overall result for 2020 equals 0.97 . Thus the profit from such an export portfolio case is negative. The information in Figure 7 starts from 2008 because the 2001-2007 data are used for the internal system calculations and forecasts.

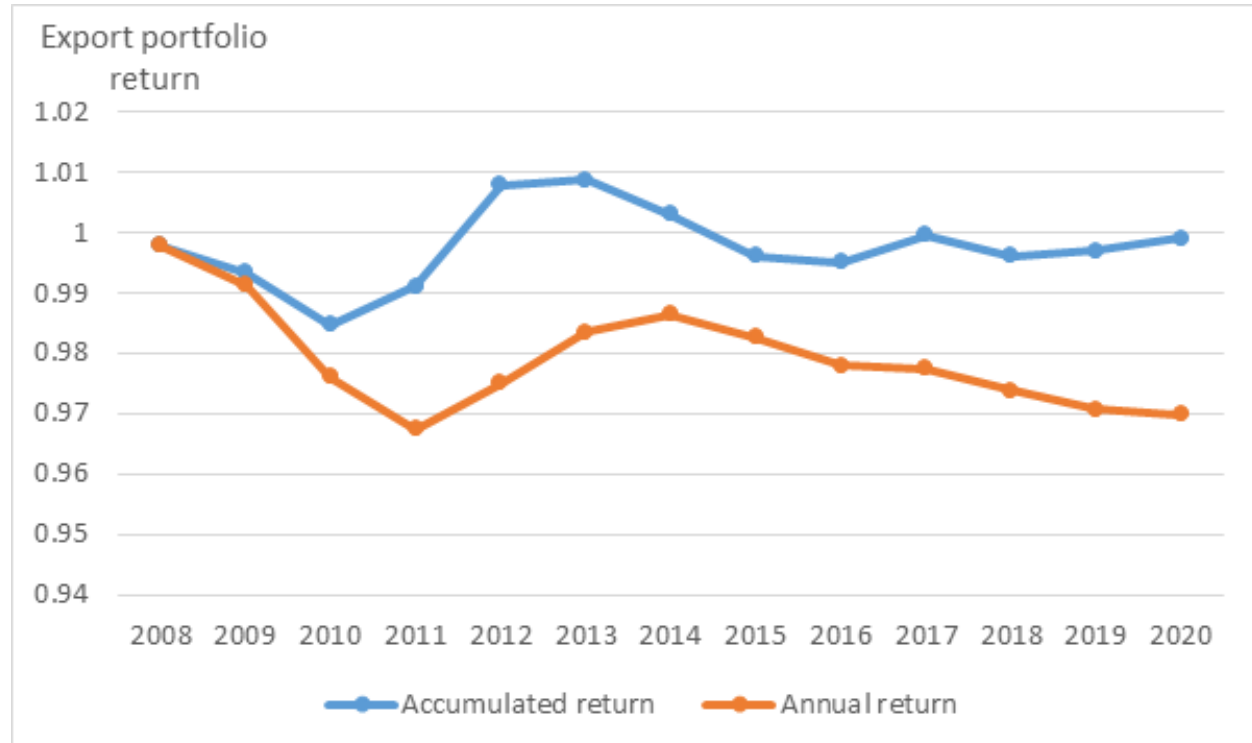

Figure 7. Portfolio annual and accumulated growth (for the case of 14 countries)

Source: Authors' calculations

\subsection{Second portfolio case}

We select seven of the 14 countries already analysed with the highest integral price growth rates and range them. These countries are Estonia, Italy, Sweden,
Belgium, Germany, Austria, and France. The presented case shows the investor's profit by exporting an equal production volume to each of seven countries. In this situation, the portfolio return at the end of the period would be 1.19 . 


\section{Journal of Contemporary Management Issues}

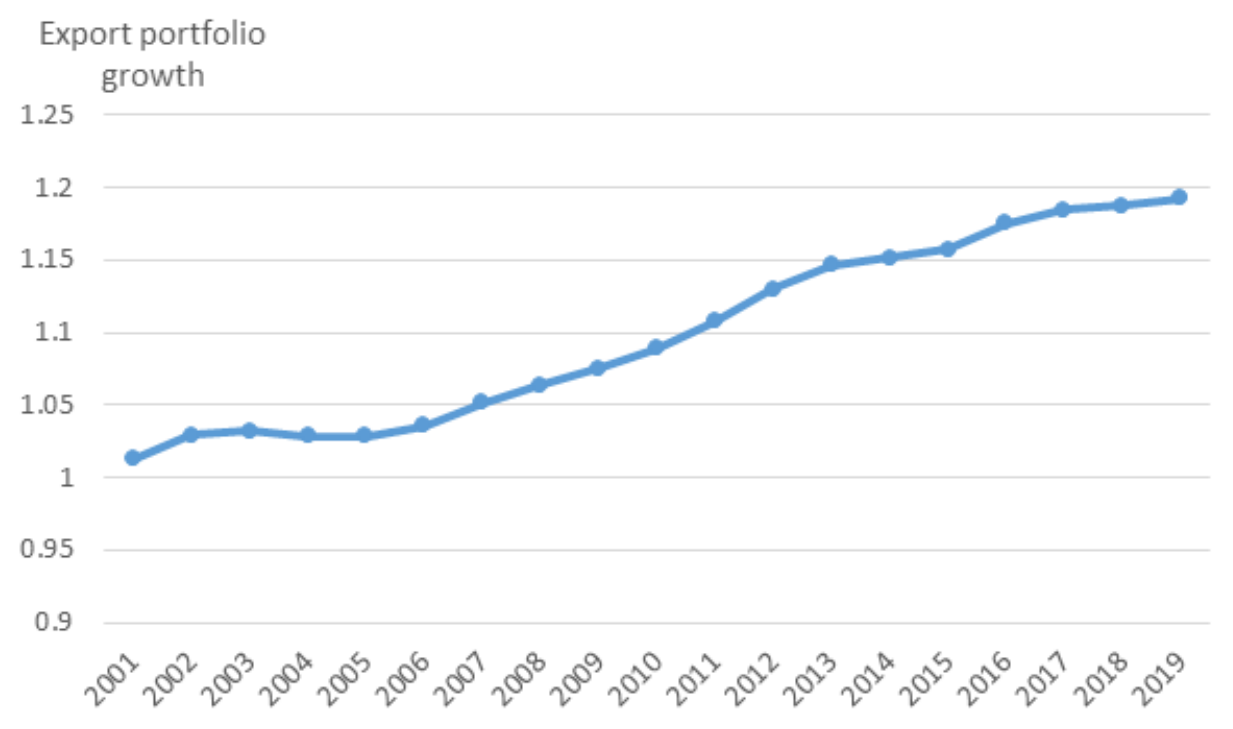

Figure 8. Export portfolio growth (for the case of seven countries)

Source: Authors' calculations

\subsection{Third portfolio case}

This variant is estimated based on the forecasted clothing annual average price index growth. All 14 countries selected for the research are analysed. Table 6 shows the predicted increases in prices since 2008 because the 2000-2007 data are used for technical system calculations and forecast formation.

Table 6. Forecasts of the annual growth of the clothing annual average price index values

\begin{tabular}{|l|l|l|l|l|l|l|l|}
\hline & Belgium & Denmark & Germany & Estonia & Ireland & France & Italy \\
\hline 2008 & 1.001139 & 0.970363 & 1.005846 & 1.035716 & 0.970053 & 1.004154 & 1.007263 \\
\hline 2009 & 1.006456 & 0.989589 & 1.001696 & 1.043342 & 0.95576 & 1.004751 & 1.014897 \\
\hline 2010 & 1.003958 & 0.998333 & 1.011143 & 1.020191 & 0.894885 & 1.008877 & 1.003667 \\
\hline 2011 & 1.010046 & 1.001315 & 1.007393 & 1.027037 & 0.908212 & 1.003196 & 1.006388 \\
\hline 2012 & 1.013439 & 1.003798 & 1.018234 & 1.047176 & 0.977234 & 0.999154 & 1.001002 \\
\hline 2013 & 1.010782 & 1.007643 & 1.025133 & 1.05935 & 0.996587 & 1.020796 & 1.018879 \\
\hline 2014 & 1.024737 & 0.997418 & 1.003109 & 1.046799 & 0.976668 & 1.007756 & 1.007003 \\
\hline 2015 & 1.003813 & 0.990157 & 1.011041 & 1.025029 & 0.967384 & 0.999804 & 1.001407 \\
\hline 2016 & 1.005524 & 0.989957 & 1.005905 & 1.027483 & 0.961269 & 0.990607 & 1.002375 \\
\hline 2017 & 1.008181 & 0.964791 & 1.006281 & 1.034659 & 0.974395 & 1.003823 & 1.005596 \\
\hline 2018 & 1.004566 & 0.984004 & 1.011209 & 1.020182 & 0.960955 & 1.00118 & 1.005753 \\
\hline 2019 & 1.003656 & 0.985435 & 1.002281 & 1.009754 & 0.988503 & 0.999776 & 1.004199 \\
\hline
\end{tabular}


Management, Vol. 26, 2021, No. 2, pp. 255-276 V. Stasytytė, A. V. Rutkauskas, E. Celiešienè: SELECTION OF MARKETS FOR TEXTILE EXPORT ...

\begin{tabular}{|l|l|l|l|l|l|l|l|}
\hline 2020 & 1.008007 & 0.971077 & 1.01825 & 1.006658 & 0.988569 & 0.996473 & 1.00319 \\
\hline & Latvia & Netherlands & Austria & Poland & Finland & Sweden & UK \\
\hline 2008 & 1.019664 & 1.011094 & 1.018976 & 0.944042 & 1.002574 & 1.02172 & 0.958564 \\
\hline 2009 & 0.994751 & 1.000399 & 1.012652 & 0.949263 & 1.002099 & 0.997014 & 0.934026 \\
\hline 2010 & 0.955657 & 0.9948 & 1.014003 & 0.940135 & 1.006101 & 1.014736 & 0.919498 \\
\hline 2011 & 0.939998 & 0.993297 & 1.007723 & 0.957783 & 1.011156 & 1.021986 & 0.979556 \\
\hline 2012 & 0.98619 & 1.007525 & 1.023708 & 0.978281 & 1.018799 & 1.013917 & 1.020985 \\
\hline 2013 & 0.98399 & 1.005981 & 1.001373 & 0.9586 & 1.026704 & 0.998686 & 1.00811 \\
\hline 2014 & 1.001579 & 1.002129 & 1.00866 & 0.953278 & 0.994063 & 1.008391 & 1.010862 \\
\hline 2015 & 1.004868 & 0.991808 & 0.992622 & 0.951977 & 0.993959 & 1.007961 & 1.004503 \\
\hline 2016 & 0.99662 & 0.981233 & 0.998434 & 0.952607 & 1.004345 & 1.010893 & 1.005075 \\
\hline 2017 & 0.999519 & 1.005764 & 1.007443 & 0.953071 & 0.99369 & 1.033169 & 1.00265 \\
\hline 2018 & 0.993555 & 0.987726 & 1.012916 & 0.947551 & 0.988286 & 1.003422 & 1.025328 \\
\hline 2019 & 1.002472 & 0.998218 & 1.006062 & 0.95852 & 0.989008 & 0.999245 & 1.009904 \\
\hline 2020 & 1.01435 & 1.015677 & 1.006061 & 0.977512 & 0.99239 & 0.991296 & 0.998632 \\
\hline
\end{tabular}

Source: Authors' calculations

Table 7 presents the historical portfolio case for 2008-2020 based on the forecasted price growth. Every row indicates to what country the production should be exported in a particular year. In the real environment, there is no possibility of changing the export countries so often. Thus, we can assume a condition that the additional production is exported in a current year according to the proposed case. There is an assumption that the production has been exported to 14 or seven countries in previous

years according to the first or second variant. The export to these countries remains unchanged, and only new (additional) production is distributed for export. The last row indicates the proposition for export in 2020. According to this proposition, all production, or the additional production (one conditional unit), should be exported to Germany. However, until 2020, the portfolio proposed exporting the production to Estonia for a relatively long time.

Table 7. The proposed portfolio structure in 2008-2020

\begin{tabular}{|l|c|c|c|c|c|c|c|c|c|c|c|c|c|c|}
\hline & BE & DK & DE & EE & IE & FR & IT & LV & NL & AT & PL & FI & SE & UK \\
\hline 2008 & 0 & 0 & 0 & 1 & 0 & 0 & 0 & 0 & 0 & 0 & 0 & 0 & 0 & 0 \\
\hline 2009 & 0 & 0 & 0 & 1 & 0 & 0 & 0 & 0 & 0 & 0 & 0 & 0 & 0 & 0 \\
\hline 2010 & 0 & 0 & 0 & 1 & 0 & 0 & 0 & 0 & 0 & 0 & 0 & 0 & 0 & 0 \\
\hline 2011 & 0 & 0 & 0 & 1 & 0 & 0 & 0 & 0 & 0 & 0 & 0 & 0 & 0 & 0 \\
\hline 2012 & 0 & 0 & 0 & 1 & 0 & 0 & 0 & 0 & 0 & 0 & 0 & 0 & 0 & 0 \\
\hline 2013 & 0 & 0 & 0 & 1 & 0 & 0 & 0 & 0 & 0 & 0 & 0 & 0 & 0 & 0 \\
\hline 2014 & 0 & 0 & 0 & 1 & 0 & 0 & 0 & 0 & 0 & 0 & 0 & 0 & 0 & 0 \\
\hline
\end{tabular}




\section{Journal of Contemporary Management Issues}

\begin{tabular}{|l|l|l|l|l|l|l|l|l|l|l|l|l|l|l|}
\hline 2015 & 0 & 0 & 0 & 1 & 0 & 0 & 0 & 0 & 0 & 0 & 0 & 0 & 0 & 0 \\
\hline 2016 & 0 & 0 & 0 & 1 & 0 & 0 & 0 & 0 & 0 & 0 & 0 & 0 & 0 & 0 \\
\hline 2017 & 0 & 0 & 0 & 1 & 0 & 0 & 0 & 0 & 0 & 0 & 0 & 0 & 0 & 0 \\
\hline 2018 & 0 & 0 & 0 & 0 & 0 & 0 & 0 & 0 & 0 & 0 & 0 & 0 & 0 & 1 \\
\hline 2019 & 0 & 0 & 0 & 0 & 0 & 0 & 0 & 0 & 0 & 0 & 0 & 0 & 0 & 1 \\
\hline 2020 & 0 & 0 & 1 & 0 & 0 & 0 & 0 & 0 & 0 & 0 & 0 & 0 & 0 & 0 \\
\hline
\end{tabular}

Source: Authors' calculations

The overall return of this case, accord- 1.51. The return in each year is shown in ing to the forecasting system, amounts to Figure 9.

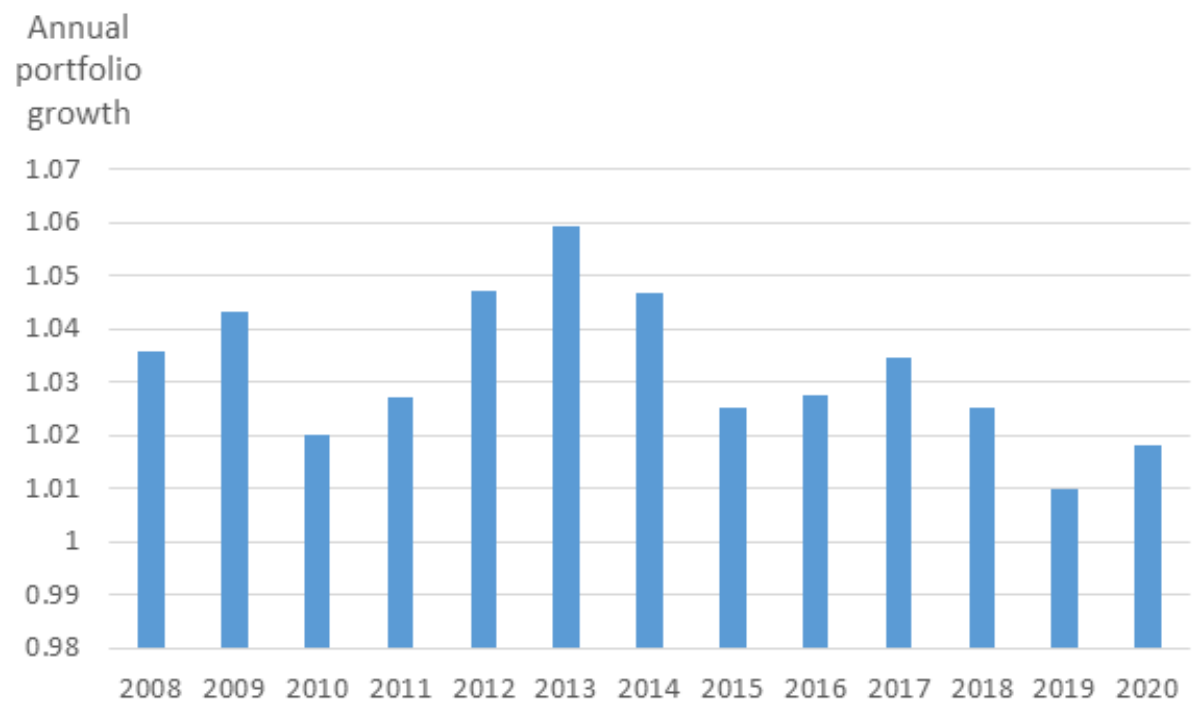

Figure 9. The annual return of the proposed portfolio

Source: Authors' calculations

The scheme of returns on exports discloses how the return can fluctuate under market fluctuations to the positive or negative side. Figure 10 shows how the accumulated utility of sales grows using the optimal strategy. The data are presented since 2009 rather than 2008 because at least two values are required to estimate the standard deviation. 


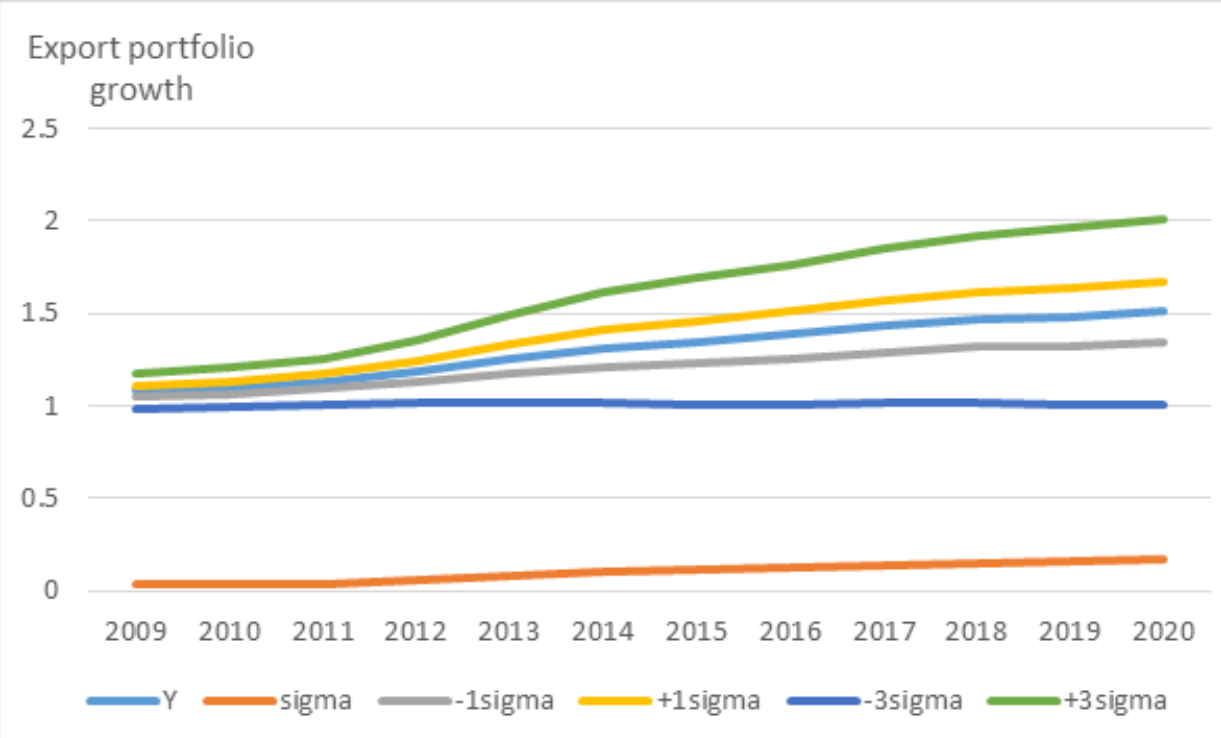

Figure 10. Confidence intervals and standard deviation of the return on export Source: Authors' calculations

In Figure 10, the $\mathrm{Y}$ curve shows the most expected portfolio value, -1sigma, which is the lowest reliability limit of one sigma level, +1sigma, which is the highest reliability limit of one sigma level, and sigma itself, which is the standard deviation. Thus under the most expected case, in 2020, the overall utility from sales accounts for 1.51. -1 sigma and +1 sigma also show the $68 \%$ confidence interval. It means that there is a $68 \%$ probability that the sales of the conditional unit would guarantee a return level of 1.34 to 1.68 to the exporter. Figure 10 also shows the confidence interval from -3 sigma to +3 sigma, which indicates a 99.7 confidence level. The portfolio values from 1.01 to 2.01 fall into this level. The presented figure provides important information to the exporter on risk resistance issues, including possible return volatility (standard deviation). While forecasting sales in the latest years, the standard deviation increases, which increases the size of the -1 sigma to +1 sigma and -3 sigma to
+3 sigma confidence intervals; the return on export grows, as well.

\section{CONCLUSIONS}

European Union textile companies increase their competitiveness by decreasing or terminating the mass production of standard products and concentrating on the broader diversity of higher value-added products. The specific types of textiles have become popular, such as technical, medical, or aerospace textiles. In 2019, EU textile turnover accounted for 88.8 billion EUR, and clothing turnover accounted for 72.8 billion EUR. The European Union is home to 50,947 textile companies and 108,758 clothing production companies. The textile and clothing industry employees are growing older, and women dominate among the employees. The highest level of investment in the textile and clothing industry is in Italy, Germany, France, Portugal, and Poland. 


\section{Journal of Contemporary Management Issues}

Lithuania exports the majority of its textile production. Competition between Lithuania and Asian countries increases. In 2018, Lithuania produced 43 million $\mathrm{m}^{2}$ of textiles. The export of textile materials and products of Lithuanian origin in 2019 amounted to 764.8 million EUR. Lithuania exports many of its textile products to Poland, Latvia, Germany, Sweden, and Denmark. It is worth developing Lithuanian textile exports by increasing the quality of goods and adequately selecting the export countries to withstand the competition of Asian countries.

An export volume portfolio was formed while performing the export market research. The set of different foreign possible export markets was treated as a portfolio. The portfolio technique has been used to determine the optimal set of export markets where it is advisable to export textile and clothing products. The ideal proportions of the distributed production that would give the optimal utility to the exporter have also been investigated. The adequate portfolio model has been used to form the export portfolio that treats the portfolio possibilities according to three parameters: return, reliability, and risk.

Three export portfolios have been presented. In the first case, 14 countries suitable for Lithuanian export were identified, and the profitability of this case was presented, which is 0.97 . Seven countries were proposed in the second case: Estonia, Italy, Sweden, Belgium, Germany, Austria, and France. The return of this case at the end of the period amounted to 1.19. In the third case, the most profitable country for export in each year of the 2008-2020 period was proposed. In 2020, this country was Germany. The overall profitability of this case is 1.51 all over the period and 1.02 for 2020. Depending on the planned export volume and foreseen diversification scope, the exporter can use one proposed case. The exporter is also given the confidence interval of the expected return result, which reflects the market volatility.

The export country portfolio formation research used Lithuania as an example. The results can be applied to the whole country and to separate companies exporting textile production. The data used for calculations are universal; thus, the results can be applied by other European Union countries with a similar size textile industry.

The research has certain limitations. While performing the initial selection of countries, it was considered that Lithuania has the greatest export to certain countries, and 14 countries were selected. Future analyses could look at exporting to other countries. Also, the proposed portfolio cases are limited to one, seven, and fourteen countries; thus, it would be interesting to offer a case with four, five, or six countries or propose separate portfolios for EU and non-EU countries.

\section{REFERENCES}

1. Annapoorani, S. G. (2017). Social sustainability in textile industry. In Sustainability in the Textile Industry, 57-78.

2. Bathrinath, S., Bhalaji, R. K. A., \& Saravanasankar, S. (2020). Risk analysis in textile industries using AHP-TOPSIS, Materials Today: Proceedings, (in press), https://doi. org/10.1016/j.matpr.2020.04.722

3. Cadogan, J. W., Paul, N. J., Salminen, R. T., Puumalainen, K., \& Sundqvist, S. (2001). Key antecedents to "export" market-oriented behaviors: A cross-national empirical examination. International Journal of Research in 
Marketing, 18(3), 261-282. https://doi. org/10.1016/S0167-8116(01)00038-6

4. Eurostat database (2020). Available online: https:/ec.europa.eu/eurostat/ web/main/data/database

5. Facts and Key Figures of the European Textile and Clothing Industry. (June, 2020). EURATEX. Available online: https://euratex.eu/wp-content/uploads/ EURATEX-Facts-Key-Figures-2020LQ.pdf

6. Founda, A., Hassan, S. E. D., Salem, S. S., \& Shaheen, T. I. (2018). In-Vitro cytotoxicity, antibacterial, and UV protection properties of the biosynthesized Zinc oxide nanoparticles for medical textile applications. Microbial Pathogenesis, 125, 252-261, https:// doi.org/10.1016/j.micpath.2018.09.030

7. Hasanzadeh, E., Mirmohamadsadeghi, S., \& Karimi, K. (2018). Enhancing energy production from waste textile by hydrolysis of synthetic parts. Fuel, 218, 41-48.https://doi.org/10.1016/j. fuel.2018.01.035

8. International trade. Available online: https://ec.europa.eu/growth/ sectors/fashion/textiles-clothing/ international-trade_en

9. İpek, İ., \& Bıçakcıoğlu-Peynirci, N. (2020). Export market orientation: An integrative review and directions for future research. International Business Review, 29, 101659. https://doi. org/10.1016/j.ibusrev.2019.101659

10. Jaiswal, A. (2016). An Occupational Hazard and Public Health Investigation among the Fabric Workers of India. Asian Man (The) - An International Journal, 10 (2), 241-246. doi: 10.5958/0975-6884.2016.00037.2

11. Lithuanian Statistics - the official statistics' website. Available online: https://osp.stat.gov.lt/
12. Markowitz, H. M. (1952). Portfolio selection. Journal of Finance, 7(1), 77-91.

13. Markowitz, H. M. (1959). Portfolio selection: efficient diversification of investments. New York: John Wiley. 341 p.

14. MSCI. Available online: https://www. msci.com/

15. Murray, J. Y., Gao, G. Y., Kotabe, M., $\&$ Zhou, N. (2007). Assessing measurement invariance of export market orientation: A study of Chinese and nonChinese firms in China. Journal of International Marketing, 15(4), 41-62. https://doi.org/10.1509/jimk.15.4.41

16. Naginionyte, A. (2016). The golden age for the Lithuanian textile industry. Klaipeda. $29^{\text {th }}$ of June, 2016. Available online: https://klaipeda.diena.lt/naujienos/verslas/ekonomika/lietuvos-tekstiles-pramonei-aukso-amzius-773730

17. Prasad, M. M., Dhiyaneswari, J. M., Jamaan, J. R., Mythreyan, S., \& Sutharsan, S. M. (2020). A framework for lean manufacturing implementation in Indian textile industry. Materials Today: Proceedings, 33(7), 2986-2995. https://doi.org/10.1016/j. matpr.2020.02.979

18. Roy, M., Sen, P., Pal, P. (2020). An integrated green management model to improve environmental performance of textile industry towards sustainability. Journal of Cleaner Production, 271, 122656. https://doi.org/10.1016/j. jclepro.2020.122656

19. Rutkauskas, A. V. (2000). Formation of adequate investment portfolio for stochasticity of profit possibilities. Property Management, 4(2), 100-115.

20. Rutkauskas, A. V. (2005). Portfolio solutions in exchange and 


\title{
Journal of Contemporary Management Issues
}

capital markets. Business: Theory and Practice, 6(2), 107-116.

21. Rutkauskas, A. V. (2006). Adequate investment portfolio anatomy and decisions applying imitative technologies. Economics: Research Papers, 75, 52-76.

22. Rutkauskas, A. V. (2017). Insightful investment by fostering the universal development sustainability: monograph. Vilnius: Technika, 182 p. https://doi. org/10.20334/2017-010-M

23. Rutkauskas, A. V., \& Stasytyte, V. (2011). Optimal portfolio search using efficient surface and three-dimensional utility function. Technological and Economic Development of Economy, 17(2), 305-326. https://doi.org/10.3846 /20294913.2011.580589

24. Rutkauskas, A. V., \& Stasytyte, V. (2020). Stochastic informative expert system for investment. Journal of Business Economics and Management,
21 (1), 136-156. https://doi. org/10.3846/jbem.2020.11768

25. Skruibyte, I. (2010). Assessment of competitiveness of Lithuanian clothing and textile industry. Applied Economics: Systemic Research, 4(1), 105-122.

26. Sun, X., Zhou, M., \& Sun, Y. (2015). Classification of textile fabrics by use of spectroscopy-based pattern recognition methods. Spectroscopy Letters, 49 (2), 96-102. https://doi.org/10.1080/00 387010.2015 .1089446

27. Textiles and clothing in the EU. Available online: https://ec.europa.eu/ growth/sectors/fashion/textiles-clothing/ eu_en

28. The European Apparel and Textile Confederation. Available online: https://euratex.eu/news/european-textile-and-clothing-sector-consolidatessatisfactory-evolution-in-2018/

\section{IZBOR TRŽIŠTA ZA IZVOZ TEKSTILNIH PROIZVODA KORIŠTENJEM ODGOVARAJUĆEG PRISTUPA PORTFELJA}

\begin{abstract}
Sažetak
Tekstilna industrija spada među najznačajnije svjetske industrije, s obzirom na značajan opseg trgovine, izvoza te zaposlenja. U Europskoj Uniji, radi se o jednoj od ključnih industrija, koja pokušava zadržati i povećati svoju konkurentnost. Većina proizvoda sektora tekstila i odjeće se izvozi, zbog čega je nužno održati odgovarajuću orijentaciju prema izvoznim tržištima. Cilj ovog rada je utvrditi zemlje, pogodne za izvor tekstilne industrije iz Litve i sličnih zemalja, korištenjem odgovarajućeg modela portfelja. Odgovarajući model portfelja razmatra mogućnosti izvoza u skladu s trima parametrima: povratima, pouzdanosti i rizicima. Za izračune su korišteni indeksni podaci o godišnjim prosjecima, dobiveni iz Eurostatove baze podataka. Nakon što je provedeno istraživanje, predlažu se tri portfelja te se utvrđuju najprofitabilnije zemlje za izvoz, kao i odgovarajući povrati. Rezultati istraživanja se mogu primijeniti na razini cijele države, ili pojedinih izvoznih poduzeća iz tekstilne industrije.
\end{abstract}

Ključne riječi: tekstilna industrija, odjeća, izvoz, proizvodnja, portfelj, povrat, rizik, pouzdanost 